\title{
Changes of Cochlear Nerve Terminals after Temporary Noise-Induced Hearing Loss
}

\author{
Jin Kyung Seo ${ }^{1,2}$, Hyun Woo Lim³, Hong Ju Park ${ }^{1}$, Jhang Ho Pak ${ }^{2}$ and Jong Woo Chung ${ }^{1}$ \\ ${ }^{1}$ Department of Otolaryngology, Asan Medical Center, University of Ulsan College of Medicine, Seoul; and \\ ${ }^{2}$ Asan Institute for Life Sciences, Seoul; and \\ ${ }^{3}$ Department of Otolaryngology, Gangneung Asan Hospital, University of Ulsan College of Medicine, Gangneung, Korea
}

\section{일과성 소음성 난청의 회복에 따른 와우신경말단의 변화}

\author{
서진경 ${ }^{1,2} \cdot$ 임현우 $^{3} \cdot$ 박홍주 $^{1} \cdot$ 박장호 $^{2} \cdot$ 정종우 $^{1}$ \\ 울산대학교 의과대학 서울아산병원 이비인후과학교실, ${ }^{1}$ 아산생명과학연구원, ${ }^{2}$ 울산대학교 의과대학 강릉아산병원 이비인후과학교실 ${ }^{3}$
}

\author{
Received February 16, 2013 \\ Revised March 18, 2013 \\ Accepted March 26, 2013 \\ Address for correspondence \\ Jong Woo Chung, MD, PhD \\ Department of Otolaryngology, \\ Asan Medical Center, \\ University of Ulsan \\ College of Medicine, \\ 88 Olympic-ro 43-gil, Songpa-gu, \\ Seoul 138-736, Korea \\ Tel $+82-2-3010-3718$ \\ Fax $+82-2-489-2773$ \\ E-mail jwchung@amc.seoul.kr
}

Background and Objectives Overexposure to intense sound can cause temporary or permanent hearing loss. Post-exposure recovery of thresholds has been assumed to indicate reversal of damage to the inner ear without persistent consequences for auditory function. However, there was a report that acoustic overexposures causing moderate temporary threshold shift caused acute loss of afferent nerve terminals and delayed degeneration of the cochlear ganglion cells while cochlear sensory cells were intact. The purpose of the study was to evaluate the numerical changes of ribbon synapses and efferents to the outer hair cells in ears with temporary noise-induced threshold shifts.

Materials and Methods Four-week old CBA mice with normal Preyer's reflexes were used. Mice were exposed to white noise of $110 \mathrm{~dB}$ SPL for one hour. Auditory brainstem response (ABR) and distortion-product otoacoustic emission (DPOAE) were recorded before exposure and at four different post-exposure times, 1, 3, 5, and 7 days after noise exposure. Ribbon synapses and efferents near cochlear nerve terminals were stained and calculated in the control group mice at two post-exposure times, 3 and 5 days after the exposure.

Results In the noise-exposed ears, there was no loss of hair cells, in either inner hair cells or outer hair cells. ABR and DPOAE showed maximum threshold shifts after noise-exposure; they returned to the normal pre-exposure values by at day 5 . The number of ribbon synapses tended to decrease at 3 days after noise-exposure, but the number of efferent fibers was not statistically different from those of the control mice.

Conclusion Our results suggest that the loss of ribbon synapses could be related with the recovery course of temporary threshold shift, even to the point of full hearing recovery.

Korean J Otorhinolaryngol-Head Neck Surg 2013;56:206-11

Key Words Auditory hair cells · Noise-induced hearing loss · Presynaptic terminals · Synapses $\cdot$ Temporary threshold shifts.

\section{서 론}

소음성 난청은 청력 역치값이 소음 노출 전 상태로 회복되는 일과성 역치변동(temporary threshold shifts)과 영구적인 난청 이 발생하여 청력이 호전되지 않는 영구적 역치변동(perma- nent threshold shift)으로 나눌 수 있다. ${ }^{1)}$ 영구적 역치변동은 와우의 유모세포 자체의 손상이나 부동모 다발의 mechanosensory 손상에 의한다. 유모세포는 소리에 의한 기계적인 움 직임을 수용기 전위로 변환하고, glutamate 분비를 통해 신호 를 전달하는 와우신경 구심성 섬유로의 시냅스(glutamate 시 
냅스)를 형성한다. 영구적 역치변동에서 유모세포 손상은 소음 노출의 수분 이내부터 발견할 수 있고 이후 수일간에 걸쳐 유모 세포의 세포사가 진행되며 나선신경절 세포(spiral ganglion cell) 의 손상은 소음 노출의 수개월에서 수년 후 확인할 수 있다. ${ }^{2.3)}$

일과성 역치변동의 경우 유모세포의 손실이 관찰되지는 않 지만 glutamate 시냅스에서 신경 말단의 glutamate 흥분독성 (excitotoxicity)에 의한 와우신경말단의 부종을 소음 노출 후 24 시간 내에 전자현미경을 통해 관찰할 수 있다. ${ }^{4}$ 소리 자극에 의 한 이러한 흥분독성은 glutamate 길항제로 억제될 수 있고 역 으로 소리 자극이 없이도 glutamate 항진제를 이용하여 비슷 한 신경말단의 부종을 유발할 수도 있다. ${ }^{5-8)}$ 일과성 청력변동 에서 이러한 glutamate 시냅스의 구조적인 변화는 청각의 회복 과 함께 회복되는 경향을 보이며, 이것은 시냅스 구조물의 회복 과 재생에 의한 것으로 생각되고 있다. ${ }^{9-11)}$

본 연구는 일과성 소음성 난청의 동물모델의 청력회복 과정 에서의 와우신경말단의 변화를 관찰하고자 하였으며, 이를 위 해 면역형광염색을 통해 관찰할 수 있는 구조물인 유모세포의 구심성 시냅스 말단의 리본 시냅스(ribbon synapse)와 내이 신 경터미널에 존재하는 원심성신경섬유의 변화를 관찰하였다.

\section{재료 및 방법}

\section{실험동물 및 실험군의 설정}

실험동물로는 정상적인 Prayer's reflex를 보이고, 청성뇌간 유발반응(auditory brainstem response, $\mathrm{ABR}$ )에서 정상청력 을 보인 4주령 CBA 마우스(Central Laboratory Animal Inc., Seoul, Korea)를 사용하였다.

청력 측정을 위해서 16 마리의 $\mathrm{CBA}$ 마우스를 사용하였으며 대조군 4 마리와 소음 노출군 12 마리의 기저 청력을 측정하였 다. 일과성 역치변동을 유도하기 위해 소음 노출군은 소음에 노출하였다. 소음 노출 이후의 역치 측정 시점은 소음 노출 직 후, 노출 후 $1,3,5,7$ 일째로 정하였다.

조직관찰을 위해 8 마리의 대조군 마우스와 소음 노출 3 일째 와 5 일째에 각각 5 마리의 마우스를 이용하여 관찰하였다.

\section{소음 노출}

소음을 주기 위해 외부소음과 차단도 되고 방음이 가능한 방 음실을 제작하여 사용하였다. 각각 $8 \Omega$ 의 입출력 저항을 가지 는 스피커(290-8L, ALTEC LANSING, Oklaholna City, OK, USA)와 증폭기(R-399, INTER M, Seoul, Korea)를 직접 연 결하여 사용하였다. 증폭기를 방음실의 좌측코너에 위치시킨 후 그 위에 스피커를 설치한 다음 horn이 $45^{\circ}$ 각도로 놓이게 하 였다.
실험군은 1 시간 동안 소음에 노출하였으며, 소음은 $110 \mathrm{~dB}$ SPL의 광대역 백색잡음 $(300 ~ 10000 \mathrm{~Hz})$ 을 이용하였다. 방음 실 안에서 발생되는 소음을 중앙부와 각각의 모서리에서 sound level meter(B\&K, Naerum, Denmark)로 측정하여 모두 110 $\mathrm{dB}$ SPL 이상임을 확인하였다.

\section{청력 역치의 측정}

역치 측정시 실험동물의 마취는 zolazepam/tiletamine( 25 $\mathrm{mg} / \mathrm{kg}$ )와 xylazine $(10 \mathrm{mg} / \mathrm{kg})$ 을 복강내로 주사하여 마취하였 으며, 필요시 상기 주사량의 반을 추가로 주사하였다. 청성뇌간 유발반응검사(ABR)와 변조이음향방사(distortion-product otoacoustic emission, DPOAE)를 이용하여 청력 역치를 측정 하였다. 청성뇌간유발반응은 TDT auditory evoked potentials workstation(Tucker-DavisTechnologies, Alachua, FL, $\mathrm{USA}$ )을 사용하여 검사하였으며 자극음은 tone burst sound를 이용하여 주파수 특이 $\mathrm{ABR}$ 을 측정하였다. 측정한 주파수는 4 $\mathrm{k}, 8 \mathrm{k}, 16 \mathrm{k}, 32 \mathrm{kHz}$ 였으며 자극음을 $90 \mathrm{~dB} \mathrm{nHL}$ 의 강도부터 $5 \mathrm{~dB}$ 씩 낮추면서 측정하여 파형을 얻었으며, 얻어지는 파형들 중 가장 일정하게 발현되는 파형을 분석에 사용하였다. 반응의 진폭이 $0.2 \mu \mathrm{V}$ 이상이면서 직전자극음에 의한 반응과 유사한 모양을 보이는 파형을 유의한 파형으로 판단하였다. 유의한 반 응을 보이는 최소자극음강도를 청각역치로 결정하였고 소음 노 출 전후 청각역치의 변화값(threshold shift)을 계산하였다. 변 조이음향방사는 동일한 검사기기를 이용하여 두 개의 자극음 을 동시에 줄 수 있는 amplifier 시스템을 이용하여 측정하였 다. F1과 f 2 의 primary tone 자극음(f2/f1=1.2)을 dual channel synthesizer를 이용하여 발생시켜서 마우스의 외이도에 장착한 acoustic probe(ER-10B+)를 통하여 자극하였다. 방사되어 나 오는 외이도의 음을 probe에 부착된 마이크를 통하여 44100 $\mathrm{Hz}$ 의 속도로 취한 후 4096 point fast Fourier transform를 이 용하여 분석하였다. F2의 자극음을 $4 \mathrm{kHz}, 5.6 \mathrm{kHz}, 8 \mathrm{kHz}$, $11.3 \mathrm{kHz}, 16 \mathrm{kHz}$ 로 정하여 나머지 변수들을 구하고 이에 따 라 자극음을 구성하였다. 각 주파수에서 측정된 그래프에서 $\mathrm{f} 1$ 과 f 2 의 앞부분에 찍혀지는 측정값이 노이즈에 묻히지 않고 위로 솟아 있을 경우를 반응한다고 판단하여 역치값을 측정하였다.

\section{조직처리 및 면역염색}

소음 측정이 끝난 마우스들을 관류고정을 통해 안락사 후 와 우를 채취하여 PBS 용액에 잠시 보관하였다. 고정액(4\% paraformaldehyde)에 1 2일 보관 후 EDTA 용액에 4 5일 보관한 뒤 실체 현미경(stereo microscope)을 이용하여 와우 코르티 기 관 부분을 채취하고 조각을 분리하여 다시 고정액에 보관하거 나 면역염색을 실시하였다. 
유모세포를 관찰하기 위해 고정과정과 EDTA 용액 과정을 거쳐 조각으로 된 코르티 기관 조직을 슬라이드에 놓고 wash buffer(0.1\% PBST)로 수세한 후 5\% normal horse serum으로 1 시간 동안 blocking한 후 1차로 리본 시냅스 염색을 위한 1 : 100 mouse anti-CtBP2(antibody to $\mathrm{C}$-terminal binding protein 2, BD Biosciences, San Jose, CA, USA)와 원심성 신경 섬유 염색을 위한 1 : 1000 chicken anti-NF-H(antibody to heavy neurofilaments, Bioscience Research Reagents, Temecula, CA, USA)를 처리하였다. 2차 antibody로는 Alexa Fluor 568 및 Alexa Fluor 488(Invitrogen, Carlsbad, CA, USA) 을 사용하였다. 핵 염색은 4,9,6-diamidino-2-phenylindole (DAPI)를 사용하였다.

\section{형광현미경 관찰}

면역형광염색한 내이의 코르티 기관 조직을 형광 관찰이 가 능한 공초점 현미경(confocal microscopy, TCS SP2, Leica Microsystems, Heidelberg, Germany)을 이용하여 관찰하였다. 조직이 얇게 절편이 된 것이 아니기 때문에 슬라이드에 봉입제 를 이용하여 커버글라스로 덮어 고정한 뒤 현미경을 통하여 관 찰하였다. 공초점 현미경을 통해 80장의 단층사진을 찍어 평균 을 낸 이미지로 관찰하였다. 정량적 분석을 위해 대조군과 소 음노출군에서 리본 시냅스와 원심성 신경섬유의 수를 확인하 였으며, 와우 basal turn에서 공초점현미경으로 얻은 같은 배율 (×1260)의 이미지상 유모세포 15 개를 하나의 관찰 범위로 하 였다. 현미경의 초점을 조절하면서 내유모세포 하단부에 분포 한 리본 시냅스와 코르티 터널에 위치한 원심성 신경섬유의 수 를 관찰하였다. 리본 시냅스의 경우 하나의 내유모세포 당 리 본 시냅스의 수를 다시 계산하였고 원심성 신경섬유의 경우는 하나의 외유모세포 당 신경섬유의 수를 계산하였다.

\section{통계분석}

통계분석은 SPSS for window version 12.0(SPSS Inc., Chicago, IL, USA)을 이용하였다. 청력검사 결과와 ribbon synapse 와 원심성신경섬유 수의 변화에 대한 유의성 검증은 Wilcoxon 부호 순위 검정과 Mann Whitney 검정을 이용하여 분석하였 다. $p$ 값이 0.05 미만일 경우를 통계학적으로 의미가 있는 것으 로 정하였다.

\section{결 과}

\section{청력 역치의 변화}

소음 노출이 없는 대조군의 경우 기저 청력검사 결과, 청성 뇌간반응 검사상 $4,8,16,32 \mathrm{kHz}$ 에서 각각 $27.5,22.5,30$,
$32.5 \mathrm{~dB} \mathrm{nHL}$ 의 청력 역치를 보였고 이는 7일째까지 변화가 없 었다. 변조이음향방사검사의 결과도 초기에 $4,5.6,8,11.3,16$ $\mathrm{kHz}$ 에서 각각 $40,40,40,35,30 \mathrm{~dB}$ SPL이었고 7일째까지 큰 변화를 보이지 않았다.

소음 노출군의 청력 역치는 소음 노출 후 모든 주파수에서 증가하여 소음 노출 전의 청력 역치와 차이를 보이다가 소음 노 출 5일째에 정상 청력과 유사해졌다. 12 마리의 마우스를 이용 하여 소음 노출 전후의 청력을 비교한 결과 소음 노출 전 평균 청력은 $4,8,16,32 \mathrm{kHz}$ 에서 각각 $25 \pm 3.1,22.5 \pm 2.0,30 \pm 5.0$, $35 \pm 5.0 \mathrm{~dB} \mathrm{nHL}$ 이었으나 소음 노출 직후 각각 $82 \pm 8.5,85 \pm$ $10.5,80 \pm 7.0,80 \pm 7.5 \mathrm{~dB} \mathrm{nHL}$ 로 증가하였고 이는 서서히 회복 되어 소음 노출 5 일째 각 주파수별로 각각 $27.5 \pm 5.5,25 \pm 5.0$, $30 \pm 5.0,32.5 \pm 5.0 \mathrm{~dB} \mathrm{nHL}$ 로 회복되어 소음 노출 전의 청력 역 치와 통계적으로 유의한 차이를 보이지 않았다(Fig. 1). 변조이 음향 방사 역치의 변화도 소음 노출 직후 $4,5.6,8,11.3,16 \mathrm{kHz}$ 에서 각각 $40 \pm 5.0,40 \pm 5.0,35 \pm 5.0,45 \pm 5.0,60 \pm 5.0 \mathrm{~dB} \mathrm{SPL}$ 로 역치가 증가하였다. 그러나 $5.6,8,11.3 \mathrm{kHz}$ 에서는 소음 노 출 후 3 일째, $4 \mathrm{kHz}$ 에서는 소음 노출 후 5 일째, $16 \mathrm{kHz}$ 에서는 소음 노출 후 7일째부터 $10 \mathrm{~dB} \mathrm{SPL}$ 이내로 회복되었으며 소음 노출 전과 통계적인 차이를 보이지 않았다(Fig. 2).

\section{리본 시냅스 및 원심성 신경섬유의 정량적 변화}

Anti-CtBP2에 의해 염색된 리본 시냅스 부위는 붉은색, Anti-NF-H에 의해 신경섬유가 염색된 곳은 녹색, 그리고 DAPI에 의해 염색된 핵은 파란색으로 관찰된다(Fig. 3). 세 개 의 외유모세포 줄과 한 개의 내유모세포 줄이 나란히 관찰되고

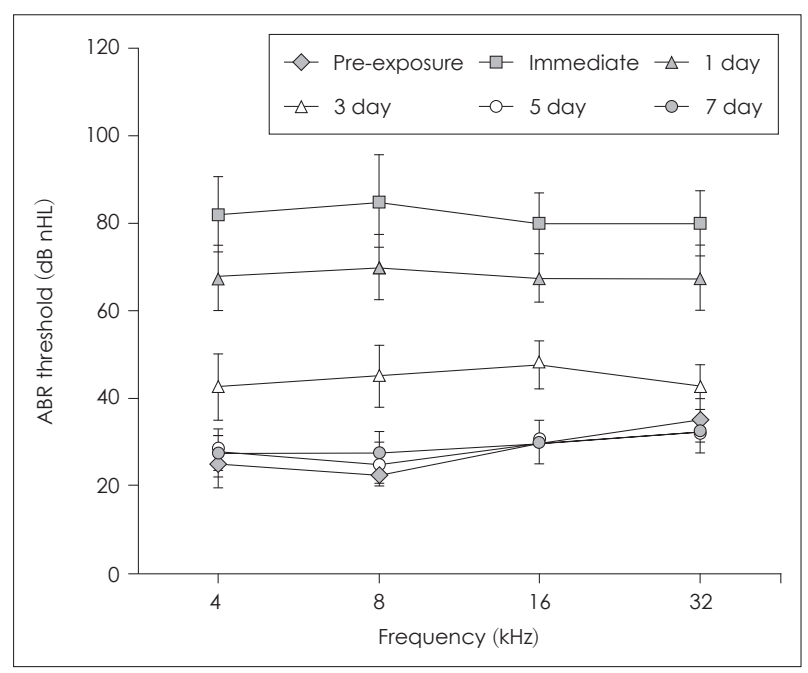

Fig. 1. ABR thresholds after noise overexposure. Broadband white noise of 1 hour $110 \mathrm{~dB}$ SPL induced temporary threshold shifts at 4-32 kHz immediate after exposure. The hearing level recovered to pre-exposure level in 5 days after noise exposure $(n=12)$. ABR: auditory brainstem response. 
유모세포 주위에 점성으로 분포한 것이 리본 시냅스들이며 내 유모세포와 외유모세포 사이에 존재하는 녹색의 섬유가 원심 성 신경섬유를 나타낸다.

소음 노출을 전후하여 유모세포의 수적 차이는 관찰되지 않았다. 리본 시냅스의 경우 청력이 회복되기 시작하는 소음 노 출 후 3 일째 한 개의 내유모세포 당 리본 시냅스의 수는 소음 노출 전 대조군의 $8.7 \pm 2.8$ 개에서 $6.8 \pm 1.3$ 개로 $21.9 \%$ 줄어들었 고 $(p=0.06)$, 소음 노출 후 5일째는 $8.0 \pm 2.1$ 개로 소음 노출 전보 다 $8 \%$ 가량 감소한 소견을 보였다 $(p=0.31)(\mathrm{Fig} .4)$. 통계적으로 유의한 차이는 아니었으나 소음 노출에 의한 청력 역치의 감소 가 확인되는 3일째에 ribbon synapse의 수적 감소가 동반되는 경향을 확인할 수 있었다. 반면, 한 개의 외유모세포 당 원심 성 신경섬유의 숫자는 소음 노출 전 대조군의 $1.10 \pm 0.09$ 개에 서 소음 노출 3 일째 $1.10 \pm 0.12$ 개, 소음 노출 5 일째 $1.02 \pm 0.14$ 개 로 소음 노출 후 별다른 차이를 보이지 않았다(Fig. 4).

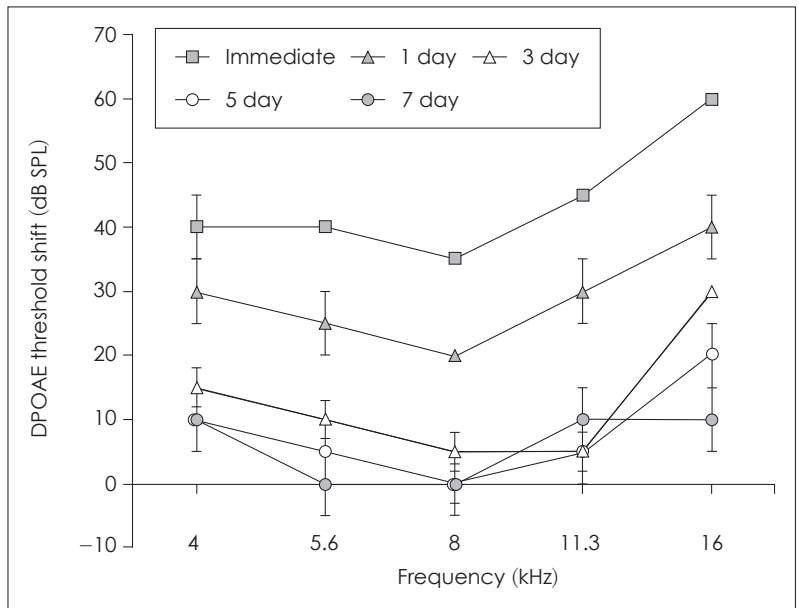

Fig. 2. DPOAE threshold shifts after noise overexposure. Broadband white noise of 1 hour $110 \mathrm{~dB}$ SPL induced temporary threshold shifts in hearing at $4-16 \mathrm{kHz}$ of the f2 frequency immediate after exposure. Elevated thresholds recovered near to the pre-exposure levels in 3-7 days according to the frequencies $(n=12)$. DPOAE: distortion-product otoacoustic emission.
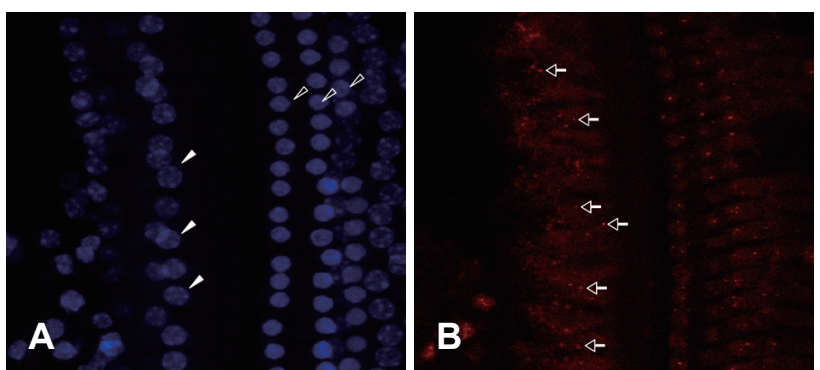

\section{고 찰}

내이의 리본 시냅스는 주로 내유모세포 말단부위에 있으며 수용전위의 변화에 의해 반응하고, 이때 주로 glutamate가 분 비된다. ${ }^{12)}$ 분비된 glutamate는 구심성 신경 말단부의 수용체를 자극함으로써 와우신경을 자극하게 된다. ${ }^{13)}$ 이러한 과정을 통 해 소리 신호는 내유모세포를 통해 와우신경을 자극하여 소리 를 감지할 수 있게 된다.

Kujawa와 Liberman ${ }^{14}$ 은 일과성 청력 역치변동을 일으키는 소음자극을 주었을 때 청력은 정상으로 회복된다고 하여도 시 냅스와 관련된 신경의 손상이 발생할 수 있음을 보고한 바 있 다. 즉, 일과성 역치변동에 상응하는 소음 자극을 주었을 때, 청 성뇌간반응 및 변조이음향방사에서의 역치가 정상으로 회복되 고 감각유모세포의 손상은 발견되지 않지만 내유모세포 말단 의 구심성신경섬유의 변화가 관찰되었다. 또한 일과성 역치변 동 후 청력은 회복된다고 하여도 내유모세포 말단의 리본 시

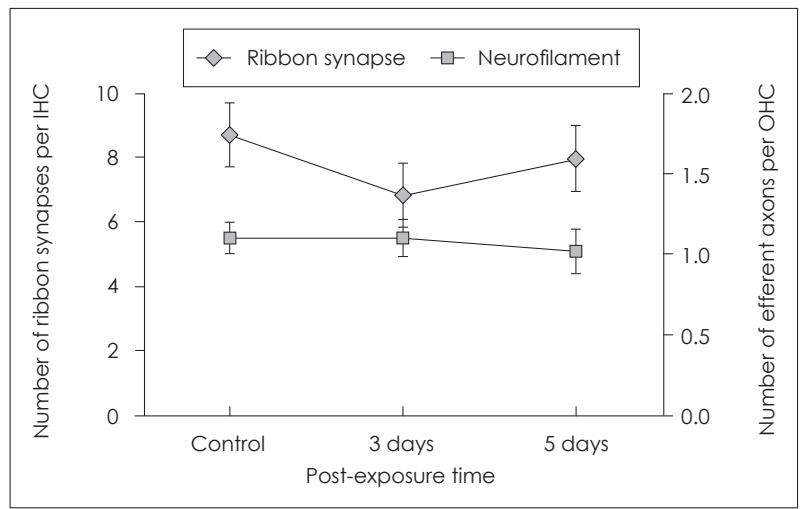

Fig. 4. Changes of the number of cochlear nerve terminal structures. Number of ribbon synapses per IHC (inner hair cell) and that of efferent axon per OHC (outer hair cell) were demonstrated according to the post-exposure time. At 3 days after noise exposure, number of ribbon synapse decreased to $78.1 \%$ of the preexposure control group without statistical significance. Number of efferent axons shows no remarkable difference among observation period ( $n=8$ for pre-exposure, $n=5$ for each of 3 days and 7 days of post-exposure).

Fig. 3. Confocal fluorescence microscopy images of the cochlear basal turn at 3 days after noise overexposure. A nuclear dye for hair cells, DAPI (blue), stained inner hair cells (filled arrow heads) and outer hair cells (unfilled arrow heads)(A). Synaptic ribbons are stained with anti-CtBP2 antibody (red). Open arrows indicate synaptic ribbons of inner hair cells (B). Filled arrows show efferent nerve axon neurofilaments crossing the tunnel of Corti stained using anti-NF-H antibody (green)(C). A merged image displays spatial correlation of hair cells, synaptic ribbons, and neurofilaments (D). DAPI: 4,9,6-diamidino-2-phenylindole. 
냅스의 수가 감소하며 이러한 손상은 반복적인 소음 자극에 의 해 더 항진되어 결국 영구적 청력 역치변동까지 발생할 수도 있다. ${ }^{15)}$ 이러한 결과들은 소음 노출 후 리본 시냅스와 신경섬 유의 손상이 있더라도 어느 정도까지의 손상은 정상 청력 역 치로의 회복이라는 결과를 나타낼 수 있다는 것을 의미한다.

본 연구는 소음 노출에 따른 일과성 청력 역치변동 후 청신경 신경말단의 변화를 정량적으로 알아보기 위해 내유모세포 주 위의 리본 시냅스의 수적 변화와 외유모세포를 지배하는 원심 성 신경섬유의 수적 변화를 확인하고 청력 역치 변화와의 관 계를 평가하고자 하였다.

이번 연구의 일과성 청력 역치변동 마우스 모델의 경우 소음 노출 후 청성뇌간유발반응에서 청력 역치의 변화가 일시적으 로 나타나지만 소음 노출 5일 이후 정상군과 같이 회복되었다. 변조이음향방사에서는 정상군보다 소음 노출 후 5일째까지 역 치값의 차이가 나타나고 7일 이후부터는 몇몇 주파수에서 노 출 전과 비교하여 약간의 역치 차이가 있었지만 청성뇌간유발 반응과 마찬가지로 청력의 통계적인 차이를 보이지 않았다. 이 러한 결과는 소음 노출 후 청성뇌간유발반응을 통한 청력 호전 이 이루어질 때 변조이음향방사를 통한 외유모세포 기능도 호 전이 동반되지만, 청력 회복 초기에 경도의 외유모세포의 기능 적인 이상이 남아있을 수 있음을 의미한다. 그러나, 원심성 신 경섬유 수의 정량적 분석을 한 결과 신경섬유 수에 변화가 없 어 원심성 신경섬유의 구조적 이상은 동반되지 않음을 시사하 는 소견으로 볼 수 있었다.

신경섬유는 원심성 섬유와 구심성 섬유로 나누어지고 변조 이음향방사와 연관된 외유모세포의 활동에는 원심성 신경섬유 가 관여한다. 리본 시냅스가 관찰되는 현미경 시야에서 신경터 미널 내에서는 주로 원심성 섬유가 관찰되기 때문에 본 연구에 서 관찰한 신경섬유를 주로 외유모세포로의 원심성 신경섬유 라고 생각할 수 있다. 본 연구에서 신경섬유의 정량적 변화를 관찰할 수 없었다는 점은 외유모세포의 기능인 $\mathrm{DPOAE}$ 의 완 전회복과 상응하는 소견이라 볼 수 있다.

소음 노출 후 3일째 청력 역치가 회복되지 않은 상태에서 리 본 시냅스의 수가 감소되는 경향 $(p=0.06)$ 을 보였으며, 이는 리 본 시냅스 수의 감소와 청력 역치의 상승이 서로 연관되었을 가 능성을 시사하였다. 즉, 내유모세포의 손실이 없이도 리본 시냅 스 수의 감소에 의해 청신경의 구심성 신호가 감소되어 $\mathrm{ABR}$ 청 력 역치의 상승이 발생할 수 있다고 해석할 수 있었다. 소음 노 출 후 5일째에는 리본 시냅스의 수가 다시 증가하였지만 여전 히 대조군과 비교하여 약 $90 \%$ 정도의 수준을 유지하고 있었다.

리본 시냅스의 경우 하나의 내유모세포 당 7개 이상의 리본 시냅스가 존재하면 정상적인 $\mathrm{ABR}$ 역치를 얻을 수 있으며 영구 적 청력 역치변동은 내유모세포 당 5 개 이하의 리본 시냅스가 존
재할 때 발생하는 것으로 보고된 바 있다. ${ }^{14)}$ 또한 Wang과 Ren ${ }^{15)}$ 은 약 $40 \%$ 까지의 리본 시냅스 손상에도 정상 $\mathrm{ABR}$ 소견을 나 타낼 수 있음을 보고하였으며 추가로 소음자극에 의해 $25 \%$ 가 더 손상되면 영구적인 청력 역치변동이 발생한다고 보고하였 다. 이 연구에서 소음 노출 전 한 개의 내유모세포 당 평균 약 14.4 개, 일과성 역치변동에 상응하는 소음을 1회 자극 후에 8.7개, 2회 자극 후는 9.6개, 그리고 영구적인 청력 역치변동이 발생한 3 회 자극 후에는 5.3개의 리본 시냅스를 측정하였다.

이러한 기존 연구 결과들을 고려할 때, 본 연구에서 관찰된 리본 시냅스의 정량적인 변화가 소음 노출 후 일과성 청력 역치 변동의 과정에서 관여할 수 있음을 생각할 수 있었다. 또한 리본 시냅스 수가 최종적으로 감소되었음에도 불구하고 $\mathrm{ABR}$ 청력역치는 정상으로 나타나, 영구적 또는 일과성 청력 역치 변동을 결정 짓는 와우신경말단 변화의 특정 지점에 대한 연구 필요성을 시사하였다.

\section{Acknowledgments}

This work was supported by the National Research Foundation of Korea (NRF) grant funded by the Korea government (2010-0023182).

\section{REFERENCES}

1) Liberman MC, Dodds LW. Single-neuron labeling and chronic cochlear pathology. III. Stereocilia damage and alterations of threshold tuning curves. Hear Res 1984;16(1):55-74.

2) Wang Y, Hirose K, Liberman MC. Dynamics of noise-induced cellular injury and repair in the mouse cochlea. J Assoc Res Otolaryngol 2002; 3(3):248-68.

3) Kujawa SG, Liberman MC. Acceleration of age-related hearing loss by early noise exposure: evidence of a misspent youth. J Neurosci 2006; 26(7):2115-23.

4) Liberman MC, Mulroy MJ. Acute and chronic effects of acoustic trauma: cochlear pathology and auditory nerve pathophysiology. In: Hamernik RP, Henderson D, Salvi R, editors. New perspectives on noise-induced hearing loss. New York: Raven;1982. p.105-35.

5) Puel JL, Ruel J, Guitton M, Pujol R. The inner hair cell afferent/ efferent synapses revisited: a basis for new therapeutic strategies. Adv Otorhinolaryngol 2002;59:124-30.

6) Pujol R, Puel JL, Gervais d'Aldin C, Eybalin M. Pathophysiology of the glutamatergic synapses in the cochlea. Acta Otolaryngol 1993; 113(3):330-4.

7) Ruel J, Wang J, Rebillard G, Eybalin M, Lloyd R, Pujol R, et al. Physiology, pharmacology and plasticity at the inner hair cell synaptic complex. Hear Res 2007;227(1-2):19-27.

8) Sun H, Hashino E, Ding DL, Salvi RJ. Reversible and irreversible damage to cochlear afferent neurons by kainic acid excitotoxicity. J Comp Neurol 2001;430(2):172-81.

9) Puel JL, Ruel J, Gervais d'Aldin C, Pujol R. Excitotoxicity and repair of cochlear synapses after noise-trauma induced hearing loss. Neuroreport 1998;9(9):2109-14.

10) Zheng XY, Henderson D, Hu BH, McFadden SL. Recovery of structure and function of inner ear afferent synapses following kainic acid excitotoxicity. Hear Res 1997;105(1-2):65-76.

11) Zheng XY, Salvi RJ, McFadden SL, Ding DL, Henderson D. Recovery of kainic acid excitotoxicity in chinchilla cochlea. Ann N Y Acad Sci 1999:884:255-69.

12) Safieddine S, El-Amraoui A, Petit C. The auditory hair cell ribbon 
synapse: from assembly to function. Annu Rev Neurosci 2012;35: 509-28.

13) Glowatzki E, Fuchs PA. Transmitter release at the hair cell ribbon synapse. Nat Neurosci 2002;5(2):147-54.

14) Kujawa SG, Liberman MC. Adding insult to injury: cochlear nerve degeneration after "temporary" noise-induced hearing loss. J Neurosci 2009;29(45):14077-85.

15) Wang Y, Ren C. Effects of repeated "benign" noise exposures in young CBA mice: shedding light on age-related hearing loss. J Assoc Res Otolaryngol 2012;13(4):505-15. 